\title{
Alemanha perdida? Escolarização de crianças em colônias de imigrantes alemães no sul do Brasil
}

\author{
Ademir Valdir dos Santos
}

\section{Resumo}

Durante os séculos XIX e XX, a regiâo sul do Brasil recebeu milhares de famílias de imigrantes alemães. Eles fundaram escolas comunitárias dentro das colônias que se tornaram uma marca de identidade étnica. Porém, nas primeiras décadas do século passado essas escolas foram alvo de campanhas nacionalistas que solicitaram seu fechamento ou uma transformação completa. Este estudo tem como objetivo resgatar e analisar memórias sobre a escola com base em entrevistas realizadas com representantes de três geraçóes de descendentes de imigrantes alemáes. Quanto à metodologia mobilizada, os aspectos que descrevem sobre suas trajetórias de escolarização são analisados sob uma perspectiva etnológica embasada pelo teor dos depoimentos colhidos, por fontes documentais e na interlocução com outras pesquisas sobre as relaçôes entre a educação e a imigração em terras brasileiras. Mostra-se que as crianças foram forçadas a aprender português e mudar seu comportamento, o que causou evasão e repetência. Resultou que a perpetuação de memórias positivas ou traumáticas da escolarização é usada para reforçar e reafirmar afeiçáo, consanguinidade e o pertencimento a uma herança cultural comum. Deste modo, as representaçóes mentais dos habitantes perpetuam a ideia de fazer parte de uma Europa brasileira, ao lado da preservação social da "germanidade".

Palavras-chave: Imigração. Criança. Escola primária.

\footnotetext{
* Doutor em Educação pela Universidade Federal de São Carlos. Docente e pesquisador do Programa de Pós-Graduação em Educação da Universidade Federal de Santa Catarina (UFSC).
} 


\section{Introdução}

Durante o século XIX e nas primeiras décadas do século passado chegaram ao Brasil imigrantes vindos de várias partes do mundo, com predominância numérica daqueles de origem europeia. Neste movimento, a regiâo meridional do país recebeu milhares de famílias de imigrantes alemães: "O povoamento sistemático do Brasil meridional com imigrantes germânicos iniciou-se em 1824" (WILLEMS, 1980, p. 28).

A presença dos estrangeiros no sul do Brasil iniciou o transplante e manutenção dos seus traços culturais. A vida social nas comunidades de imigrantes foi se caracterizando de modo particular na organização da família, nas associações religiosas, na organização política e econômica, nos clubes recreativos e esportivos e nas escolas, construindo diferenciações quando comparada ao entorno. A língua utilizada era a alemã ou dialetos germânicos; a fé protestante e seus ritos contrastavam com o contexto brasileiro até então exclusivamente católico; atividades profissionais e comerciais especializadas que eram comuns na Europa, mas ainda pouco desenvolvidas no ambiente local começaram a ser desenvolvidas; o canto, a dança, o teatro, a ginástica, o bolão e o tiro continuaram a ser praticados; foram criadas instituições educacionais de iniciativa própria, comunitária. Assim, foi formado um cenário com elementos étnico-culturais particulares. Começou a se esboçar o que hoje se convenciona chamar de "Vale Europeu". De modo ora harmônico, ora conflituoso, pouco a pouco foram construídas relaçóes sociais, culturais, políticas e econômicas muito mais marcadas pela herança germânica do que pelos dados tipicamente brasileiros. Como lembra Seyferth (1990, p. 79), em perspectiva etnológica:

Os imigrantes, em geral, mantêm alguma ligação com cultura e sociedade de origem, por maiores que sejam as pressôes no sentido da assimilação. Guardam sempre alguma forma de identificação étnica, por mais que os laços com seus países de origem estejam diluídos. Assim, os fenômenos chamados pelos especialistas de "absorçáo", "assimilação" e "aculturação" náo impedem a persistência do componente étnico da identidade social dos descendentes de imigrantes, por mais que estes estejam integrados à nova sociedade. Para a maioria deles, a identidade étnica é relevante, e indivíduos com a mesma origem tendem a formar grupos étnicos mais ou menos organizados. 
Quando se examinam aqueles contextos históricos, é principalmente à escola que se atribui o papel central na conformação de uma identidade étnica que deu origem e sustentou representações mentais individuais e coletivas partilhadas pelos imigrantes alemães e sua descendência. Vários pesquisadores afirmam que a escola foi eleita pelos colonizadores alemáes como um dos meios eficazes para combater a decadência cultural. As "escolas alemãs" foram responsabilizadas por uma educação em bases sólidas das crianças e pela salvaguarda dos valores culturais estrangeiros: "A escola como alfabetizadora, a escola como fiadora da religião e da religiosidade, a escola como guardiã dos valores culturais assumia mais uma importante função" (RAMBO, 2003, p. 78).

Mas que tipo de instituição escolar foi fundada? Primeiro, é fundamental dizer que as escolas fundadas pelos imigrantes alemães eram comunitárias, organizadas por eles e construídas com base no seu próprio esforço. Isto porque até a metade do século XX eram poucas as escolas primárias públicas mantidas pelo governo brasileiro em seu território. $\mathrm{Na}$ educaçáo escolar persistia um quadro que conservou características dos períodos Colonial (1500-1822) e Imperial (1822-1889), em que existiam quase que exclusivamente instituiçóes escolares privadas e que atendiam à elite local. No período republicano foram registrados raros investimentos estatais na educação elementar da criança brasileira, quer na Primeira República ou República Velha (1889-1930) como na Segunda República (1930-1945). O descaso do Estado brasileiro com a educação é visto como um dos fatores que levou os imigrantes a fundar suas próprias escolas. E cabe lembrar que a necessidade que os imigrantes atenderam de fornecer instruçáo para seus filhos tinha raízes na tradição de escolarização já instalada na cultura europeia ocidental. Notadamente este sentimento estava presente entre os imigrantes alemáes luteranos, pois é conhecido o valor dado à escola no ideário de Martinho Lutero e que foi trazido como herança e preservado no contexto brasileiro. E mesmo os imigrantes alemães católicos erigiram suas escolas. As escolas comunitárias fundadas foram uma das peculiaridades da organização social nas áreas coloniais.

Este estudo tem como objetivo resgatar e analisar memórias sobre a escola com base em entrevistas realizadas com representantes de três geraçôes de descendentes de imigrantes alemães. Quanto à metodologia mobilizada, os aspectos que descrevem sobre suas trajetórias de escolarizaçáo são analisados sob uma perspectiva etnológica embasada pelo teor dos depoimentos colhidos, por 
fontes documentais e na interlocução com outras pesquisas sobre as relaçōes entre a educação e a imigração em terras brasileiras.

\section{Dos primórdios}

Um dos pontos de partida é o depoimento de Willy Julio Otto Früchting ${ }^{1}$, descendente de primeira geração, nascido em 1911 e aluno de uma escola alemã fundada em 1914. A instituição foi erguida na região onde sua família se estabeleceu, a pequena Hansa Humboldt, um dos quatro distritos da Colônia Hansa, empreendimento da Companhia Colonizadora Hanseática iniciado em 1897 em terras de Santa Catarina e destinado exclusivamente à ocupação com imigrantes alemães ${ }^{2}$. Suas memórias incluem aspectos do prédio escolar e didático-pedagógicos, colocando em evidência o caráter comunitário de uma escola primária construída e mantida por famílias de colonos. Era uma edificação enxaimel, estilo próprio do norte alemão, que hoje está abandonada em meio à mata. Lembra:

[...] deve de ser... ela [a comunidade] construiu isso. Para ter.. para dar um pouco de escola para os filhos, sabe como é... Os filhos nascem e crescem e não têm escola. Dai quem fez o serviço foi o Carlos Kubl, Carlos Kubl era o nome dele. Então lá eu acho que lá, acho que era uma sociedade escolar. Para mim era isso, mas particular!

Entrevistei ${ }^{3}$ em duas ocasióes distintas o núcleo familiar matrilinear composto por três geraçôes que ainda convivem: a octogenária Adele Eger, nascida em 1927, sua filha Edeltraut (Eger) Milnitz, nascida em 1950, e sua neta Maoreen Milnitz, nascida em 1988, que conjuntamente (re)elaboraram suas memórias quanto à escolarização ${ }^{4}$. As duas primeiras estudaram naquela mesma edificação citada por Willy Früchting. Assim, recordaram seu itinerário escolar, respondendo às minhas perguntas:

Entrou com oito anos? Ou todos entravam com oito? Adele: Todo mundo!

Edeltraut: Era a primeira escola aqui, por isso tinha tantos alunos, crianças acumuladas para estudar e tudo mais.

Foi logo quando a escola abriu? Foi uma das primeiras turmas? Adele: Não! Não! 
Ou a escola já existia antes?

Adele: Já tinha antes, e eu nem me lembro quando eles construiram essa escola aqui.

As depoentes indicam a escola como um elemento constituinte de sua comunidade, segundo o que transparece uma necessidade natural de se "enviar" todas as crianças à escola, que marcou como fermento e amálgama algumas das várias geraçôes de alemáes 5 .

Com base em pesquisa documental sobre as antigas escolas rurais dos imigrantes daquela região, pude levantar a origem da escola onde estudaram Willy, no início dos anos 1920, Adele, na década de 1930, e Edeltraut, nos anos de 1950. Comparei os dados com a memória oral de Walter Straatmann ${ }^{6}$, que foi entrevistado em 1998, quando tinha 84 anos. Nessa época, "Seu" Walter ainda falava exclusivamente alemão, num tom baixo, os limites do corpo se fazendo pesar. Componente da primeira geração de uma família pioneira, contou sobre o papel de seu pai na criação da escola: "O meu pai mediu o terreno que tinha mil metros. [...] 1 morgo, quando a escola era na parte de cima, ele deu 6 morgos na parte de baixo pra eles construir". Segundo ele, a primeira professora era alemã. A comunidade construiu a escola junto da igreja, depois foi feita uma emenda para a professora morar. Mais tarde, venderam tudo e fizeram uma nova escola, também com instalaçôes para o professor residir (SANTOS, 1999).

Já Maooren, da terceira geração, foi aluna da mesma "escolinha" na década de 1990. Nesse momento várias transformaçóes haviam ocorrido desde o tempo em que sua avó Adele estudara. As atividades foram transferidas para outro prédio, situado no mesmo terreno e ao lado da abandonada estrutura em estilo enxaimel da antiga escola alemá. Na época não era mais administrada pela comunidade, mas pela prefeitura.

Onde você estudou?

Maoreen: Foi aqui na frente, na escolinha, na Escola Municipalizada Rio Novo. Na época a gente frequentava de $1^{\mathrm{a} a} 4^{\mathrm{a}}$ série. Aí era $1^{\mathrm{a}} \mathrm{e} 3^{\mathrm{a}}$ série à tarde. E $2^{\mathrm{a}} \mathrm{e} 4^{\mathrm{a}}$ série de manhã.

E essa escola era uma escola nova ou ela já existia?

Maoreen: É uma escola bem antiga, só a única coisa que o prédio dela mudou, que tinha a escolinha antiga, aí mudou a residência para o terreno do lado. 
Como eram as salas?

Maoreen:Era como antigamente, era uma sala só e todas as séries, no caso divididas só por filas de carteiras. Quadro dividido ao meio. Uma série numa metade do quadro e outra série do outro. Eu achava bom enquanto estudava uma coisa eu ia acompanhando as séries que já vinham, alguma coisa, sempre já tinha alguma base. E das matérias, o que se estudava?

Maoreen: Matérias era básico: Português, Matemática, Ciências. Aí na época Geografia ainda não existia. Tinha Ensino Religioso.

A fala da jovem descendente evidencia algumas das permanências que historicamente caracterizaram aquele tipo de instituição e se relacionam intimamente com o plano social e cultural das comunidades rurais: oferta apenas do ensino primário, classe conjugando crianças de diferentes níveis de escolarização e responsabilidade de um único professor. Sobre tal organização, lembro ao leitor que, em sua maioria, as escolas de áreas rurais eram dedicadas ao ensino primário de três ou quatro anos de duração. Notadamente, aquelas fundadas no final do século XIX e nas primeiras décadas do século passado atendiam, num mesmo espaço e horário, as crianças de séries diferentes. É o que se denomina escola multisseriada, ou seja, cabia ao mestre desenvolver estratégias didáticas para atender simultaneamente crianças de idades diversas e com níveis de aprendizagem também diferenciados.

Mas as memórias recontadas por estas três geraçôes contêm vários elementos que apontam também para as transformaçóes pelas quais passaram, ao longo do século passado, muitas outras "escolas alemãs" espalhadas pelo território brasileiro. Os depoimentos dos mais velhos reconstituem aspectos das típicas escolas alemãs, onde o germanismo era forte. Já as entrevistas daqueles que estudaram a partir do final da década de 1930 indicam a convivência ambígua entre dados primordiais de inspiração na cultura alemã e elementos de aculturação de origem brasileira.

Tais mudanças são ratificadas no depoimento de Adelaide Heller ${ }^{7}$ Sua trajetória é interessante: nos anos 1940 foi aluna da própria mãe, Marta Baum, esta responsável pela docência entre 1930 e 1940 na bucólica regiáo do Rio Novo. Adelaide seguiu a carreira docente e acabou atuando como professora primária entre as décadas de 1950 e 1970. Nascida em 1932, guarda recordaçôes 
sobre a sua atuação e a da mãe. Afirmou segura: "Filho de peixe, peixinho ê". Em alguns momentos comparou a lida profissional materna com a própria: "Muito mais sacrificado que no nosso tempo?". Adelaide recuperou lembranças pessoais sobre o primeiro prédio escolar, reafirmando aspectos da história da velha escola, apresentada como um espaço de preservaçâo da cultura dos imigrantes, particularmente quanto aos usos do idioma estrangeiro:

Num prédio de madeira do outro lado da rua. Um barranco,
para dizer. Era uma casa muito pequeninha. E diz que
nessa casa quem foi um dos professores foi um Hertenstein,
que dava aula alemá. Falando em alemáo. Assim eu tive
informaçóes através de um tal de Linzmeier, que já é
falecido há muitos anos, nem o nome dele eu náo sei mais.
Este terreno, esta escola, foi doada pelo Straatmann, dos
velhos Straatmann, esse terreno. Que para facilitar, então
os Straatmann resolveram trocar: deram o terreno abaixo da
rua e ficaram com a parte que era acima da rua. Epor isso,
mais tarde, os colonos, o próprio povo fez a casa da escola,
junto com a morada do professor, para facilitar, porque
senão o professor tinha que ser defora e não tinha onde ficar.

O conteúdo permite identificar alguns traços típicos dessas instituiçóes que imprimiram uma marca peculiar na história da educação brasileira. Nos primórdios, devido às dificuldades econômicas dos recém-chegados, a escola podia ter sede em alguma residência familiar. Aos poucos, com o desenvolvimento econômico local, foram construídos prédios para uso escolar $\mathrm{e}$, frequentemente, também para práticas religiosas. Quanto à arquitetura, as primeiras escolas ocupavam primitivos ranchos cobertos com folhas de palmeira; mais tarde, foram sendo erguidos edifícios de madeira ou de tijolos. Sobre a construção da mesma escola e o engajamento dos colonos, Edeltraut Millnitz trouxe, em tom de anedota, recordaçóes que evidenciam a transmissão intergeracional de componentes da memória coletiva:

Quando construiram, o velho Ganske ainda caiu da construção. Ele era muito mentiroso. Ele despencou de um andaime com um monte de tijolos. Fizeram isso do lado, aquilo despencou, aquele andaime que fizeram. Ele caiu com tijolos e tudo! Dai quando ele chegou no chão, perguntaram... Ele era muito mentiroso. Se tinha se machucado, estava todo batido! 
- Não, diz ele. Não caí.

Ele "desviou" todos os tijolos [risos]. Imagine! Nunca mais apareceu.

As vivas lembranças do quase centenário Willy Früchting misturam a satisfação pessoal e a frustração por não cursar as três séries ofertadas ${ }^{8}$, pois, segundo a visão de seu pai, o trabalho infantil na propriedade rural era mais importante do que estudar:

E frequentei a escola de janeiro de 1921 até maio de 1923. E... Eu não pude ir mais para a escola porque era o seguinte... Nós éramos gente muito pobre e o meu pai disse: - Olha, você tem que ficar em casa, ajudar na roça, porque nós não podemos mais lhe mandar para escola. Isso aconteceu, infelizmente, mas aconteceu. Eu devia de ir até dezembro naquele ano, mas o pai disse... [...] É, era pra ser até 3, é incompleto, eu fui 2 e meio.

Esse depoimento revela as contradiçóes vividas: ao mesmo tempo em que havia um entendimento de que a escola era importante para a formaçáo infantil, a subsistência familiar naqueles tempos duros exigia o trabalho das crianças e chama a atenção para um fenômeno, neste caso, os altos índices de natalidade. Afinal, quanto mais braços para o trabalho, maiores as chances de prosperidade. Criaram-se escolas porque muitos eram os nascidos nas colônias. Recorro às memórias de Adele para ilustrar esse aspecto:

E eram os meninos juntos das meninas na sala?

Adele: Aham [Afirmação].

Por que será que tinha tanta gente nessa época? Era uma unica escola que tinha na região, talvez?

Adele: E! Mas é que antigamente eles tinham muitos filhos. Ah, tinham muitos filhos! Por isso, então, todo mundo tinha que ir para a escola?

Adele: Todo mundo!

E se não fossem para a escola, não tinha, digamos assim, uma família que deixasse que a criança não fosse para escola? Adele: Não, não! 
Uma das características dessas escolas rurais é que, muitas vezes, o professor vivia na própria edificação da escola ou numa construção vizinha. Perguntei a "Dona" Adelaide se era a praxe, uma vez que ela cresceu morando na escola: "Depois dessa construção de material [enxaimel]! Mas, antes disso, não sei como é que era. Eu acredito que o Hertenstein, que diz que era professor, morava fixo por lá, tinha terreno próprio". Esse aspecto compóe um dado identitário particular da relaçáo entre comunidade e escola, entre os sujeitos do processo educativo: o professor integrava a comunidade e partilhava de seu cotidiano. As depoentes Adele e Edeltraut, mãe e filha, somaram na composição sobre essa íntima ligaçáo entre a vida pessoal e familiar do professor e sua atividade docente, nesse caso, abrigadas sob o mesmo teto:

Estudou na mesma escola da Edeltraut? E quem era a professora?

Adele: Marta Baum, primeiro. Depois ela se casou com Charles.

E como que é que a tia [Adele] contou que ela teve que se casar, a professora não podia ser solteira?

Adele: Não, não!

Edeltraut: Ela vivia com ele!

Adele: $E^{\prime}$

Edeltraut: Ela era "ajuntada", como se diz!

A comunidade não permitia?

Edeltraut: Não permitia.

Náo podia?

Edeltraut: Era preconceito.

Daí ela casou!' E a tia Adele também lembra da escola? Tinha muitos alunos na sala?

Adele: Mais do que 100!

Mais do que 100? Na mesma sala?

Adele: Na mesma sala!

E cabia tudo ali?

Adele: Cabia! Tinhas bancos bem compridos. Em cada banco tinha 10 crianças.

Edeltraut: Eram bancos grandes que atravessavam a sala de lado a lado! Na minha época depois tinha carteira só pra dois sentarem em cima, assim! Só tinha um único banco desses antigos bem no fundo... 
A natureza da atividade docente acabava por exigir que o professor fosse intimamente vinculado à comunidade, seja em relaçóes aceitas como naquelas controversas. A escola, a comunidade e suas crianças, o professor e sua família, todos conjugavam um espaço histórico que gestava uma identidade cultural comum, nutrida por costumes e valores pertinentes. $\mathrm{O}$ cotidiano doméstico e o escolar se misturavam, contribuindo na constituição de traços étnicos:

E aquilo lá que vocês estavam falando de cozinhar? Vocês cozinhavam para a professora? Você lembra de alguma coisa disso?

Edeltraut: Isso, eu ajudava a professora.

Adele: Eu também sempre ajudei a dona Marta, de manhã.

Ajudava ela, como assim?

Edeltraut: No serviço da casa.

Ela morava perto da escola?

Adele: Era dentro da escola!

A professora morava dentro da escola!

Edeltraut: Exatamente.

Adele: Dentro da escola!

Como era?

Edeltraut: Por exemplo, a nossa sala aqui. Numa construção como essa casa aqui, aquela com outra sala e junto com esse quarto era a sala de aula.

Certo!

Edeltraut: E como a cozinha aqui, isso era a moradia da professora.

Eu estive lá na escola. Então, lá naquela construção antiga, o sótão era onde ficava o quarto da professora?

Edeltraut: O quarto! Dela e do marido. Aquela parte grande onde tem a porta e a sacada virava varandinha. Aquela parte onde tem a escada que dá para o sótáo, ali era a sala de aula. Adele: $E^{\text {. }}$

Edeltraut: ,É exatamente.

$E$ atrás, onde tem o forno de lenha e o fogão à lenha, ali era a cozinha?

Edeltraut: Aham, exatamente!

E tinha alguma outra parte da escola? Biblioteca? Alguma coisa?

Adele: Nada.

Edeltraut: Não, era unicamente aquela sala. A pequena 
varanda na frente onde os alunos se abrigavam antes $d a$ aula quando era dia de chuva.

Porque a professora só abria a escola na hora da aula?

Adele: Só!

Nesse panorama, as escolas funcionavam como promotoras de identidades coletivas e individuais oriundas das raízes na imigração alemã. As memórias ratificam que as escolas eram propriedade das comunidades, por vezes dirigidas por uma sociedade escolar. Questionei sobre este aspecto, obtendo respostas que indicam transformaçôes históricas a que as escolas de imigrantes foram submetidas. Fato é que existe um Título definitivo de propriedade, datado de abril de 1918, em que a Sociedade Colonisadora Hanseatica atesta a compra do lote colonial número 122A, situado na "linha caminho Rio Novo", pela "Sociedade escolar Rio Novo" (TÍTULO..., 1918).

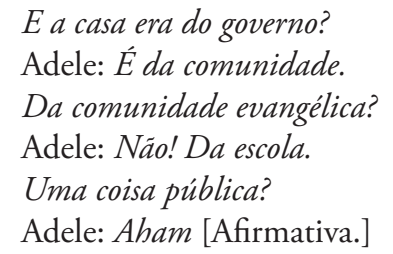

Sobre a cultura material, nota-se que havia um mobiliário rudimentar. As ferramentas didáticas como livros e cadernos de papel foram sendo gradativamente adotadas. Inicialmente, as crianças utilizavam lousas de pedra (ardósia), sobre a qual escreviam com um lápis (giz) específico que deixava traços facilmente removíveis. Sobre os suportes da escrita usados:

Edeltraut: No início não tinha caderno, eram tipo de um quadro.

Vocês não usavam caderno?

Adele: $E$, como se diz em alemão... Tafel.

Uma lousa assim! Uma pedra assim!

Adele: E!

Edeltraut: Exato.

E ai naquilo escrevia? Depois apagava assim, como era? Adele: Apagava.

Escrevia com o quê? Com carvão?

Adele: Com o lápis! Eu não sei de que era esse lápis. 
Edeltraut: Lápis especializado pra escrever.

Adele: $E$ !

Certo. Então na época da tia Adele era com essa lousa.

Adele: Mas só acho que no $1^{\circ}$ ano só, depois nós também já tinhamos caderno!

Escrevia com lápis no caderno, caneta ninguém tinha?

Adele: Caneta, caneta, ainda com aquela...

Tinteiro?

Edeltraut: Com pena!

Adele: Aham [Afirmação].

Com pena e tinteiro! A carteira tinha o buraquinho ali na frente!

Adele: E!' Potinho com a tinta. Isso borrava! Ah, cruzes! [Risos].

Borrava muito?

Adele: Muito!

De acordo com Santos (2009), os registros escritos das escolas mais antigas eram somente no idioma alemão. Com o decorrer do tempo, passa-se a ter material bilíngue alemão-português.

E o que se ensinava? Que espécie de currículo se instituiu? A entrevistada Edeltraut, que estudou no período pós Segunda Guerra Mundial, dá indicativos de que o projeto de expansão cultural norte-americano buscava fincar raízes em solo brasileiro e chegou até mesmo naquelas regióes interioranas:

Sobre outros países? Fora do Brasil, também não se aprendia? Edeltraut: Pouca coisa!

Por exemplo, já que todo mundo tinha esse possivel vinculo na família com a Alemanha, não falavam? E não se tinha nem ideia da onde ficava no mundo?

Edeltraut: Não, não! Olha da Alemanha isso não se falava! Se falava dos Estados Unidos.

Ah é!

Edeltraut: Ai sim!

Falava-se bastante dos Estados Unidos?

Edeltraut: E!

O que se falava dos Estados Unidos?

Edeltraut: Nem sei, lembro vagamente! Inclusive no mapa mundi, ficava grande na parede, mostrava o Brasil, estudava os rios, estradas de ferro, as dimensóes, tudo isso! 
Coleto outros elementos sobre a prática pedagógica ao ouvir Adele e Edeltraut, que embora estudando em décadas distintas, indicam permanência que podem ser vinculadas à chamada pedagogia tradicional, com apelos à repetição, à cópia e à memória.

Lembra o que tinha de matéria? O que estudava?

Adele: História, Geografia, antigamente era Aritmética.

Edeltraut: A Matemática e a Aritmética. Naquela época também dividir, somar enfim...

As quatro operaçōes?

Edeltraut: As quatro operaçôes! Mas a gente tinha que aprender a fazer a mediçấo do círculo! Essas coisas todas que já nâo se aprende mais, fazer conta que era dúzia, uma roda. A Aritmética eram problemas para resolver, tinha que dividir tantas e tantas laranjas e depois tantos e tantos amigos, quantas laranjas para cada um. Isso era o tema na nossa época.

E faziam os problemas no caderno?

Edeltraut: $E$, exatamente!

Tinha livro de Matemática?

Edeltraut: Não, não tinha livro. Isso a professora escrevia no quadro e a gente copiava no caderno. Resolvia, fazia a conta e depois em baixo tinha que dar a resposta direitinho como era, explicar direitinho também!

E a tabuada era tomada de vez em quando ou todo dia? Edeltraut: Não era todo dia! Mas a questão da tabuada era muito rigorosa! Tinha muita conta com números menores, número na chave e coisa e tal. Isso era meio complicado assim, às vezes [risos]. Meu Deus do céu! Às vezes até faltava um pedaço da folha em baixo e não conseguia nem concluir a conta!

Nossa, que grande!

Edeltraut: É! Contas com número na chave, mas isso às vezes dava uma conta, assim... A gente começava, ai, meu Deus do céu! Eu não era tão, tão boa assim. Tanto que eu não era um gênio! História tinha tanta coisa, mas eu decorava com facilidade sabe aquilo! Agora, conta não era assim, eu não ia tão mal. Me esforçava assim, mas isso não era o meu forte! 
Os pensamentos continuam voando, auxiliando numa avaliação do trabalho docente:

E como a professora fazia pra atender tanta gente? Uns eram da $1^{a}$ série, outros da $2^{a}$ série?

Adele: $2^{a}$ e $3^{a}$.

Edeltraut: Só tinha até a $3^{a}$ na escola!

E como é que a professora se virava com esse pessoal?

Adele: Ela mesmo se virava!

E a professora explicava e vocês escutavam?

Edeltraut: Todo mundo junto com a professora, feito uma ninhada de pinto, parado ali olhando o mapa, ela com a régua mostrava os rios e as estradas. E todo mundo em volta. E todo mundo olhando!

Edeltraut: Aham [Afirmação].

(dirigindo-se à Adele): Era desse jeito também?

Adele: Aham! [Afirmação].

Edeltraut: Desenho, matéria, caderno de desenho.

Tinha caderno de desenho! Tia Adele também?

Adele: Tinha.

E desenhava o que?

Edeltraut: Qualquer coisa a professora desenhava no quadro. E depois se copiava, desenhava e pintava, fazia tudo bonitinho.

Mas ela fazia um desenho no quadro e vocês faziam o mesmo desenho? Tinha que usar a mesma cor, como era?

Edeltraut: Não, não! Isso não! Cada qual escolhia depois.

Pintava com o que?

Edeltraut: Lápis de cor.

Adele: Mas também tinha que desenhar o mapa de Santa Catarina e também o mapa do Brasil!

Edeltraut: Tinha que ser desenhado.

Adele: $E !$

Edeltraut: Não colado, desenhado!

Adele: Desenhado! Cada pontinha, bem certinho.

Edeltraut: Exatamente

E conseguia fazer isso?

Adele: Conseguia!

E como conseguia pra fazer isso? E tinha que treinar muito? Adele: É, a gente treinava e caprichava. 
Ai sai um mapa bonitinho? Então tinha que repetir muitas vezes até.

Adele: Tinha! E a cada instante, nós tínhamos que desenhar.

Mas quem eram os professores dessas escolas? Willems (1980) defende que em alguns casos a escolha recaía sobre alguém que estava impossibilitado fisicamente de trabalhar no cultivo da terra e na criação dos animais, funçóes consideradas vitais à sobrevivência. Estudos de Rambo (1994, 1996, 2003) e de Seyferth (1990) assinalam que no princípio se escolhia entre os próprios imigrantes alguém que tinha conhecimentos da escrita, da leitura e de operaçôes matemáticas básicas, de modo que pudesse instruir as crianças com noçóes elementares úteis e aplicáveis à vida naqueles contextos. Com o passar dos anos, surgiram condiçóes de contratar professores, mesmo que estes tivessem uma formação precária, pois se sabe que instituições de formação docente foram surgindo gradativamente nas primeiras décadas do século $\mathrm{XX}$, mas o número de diplomados não atendia às necessidades da época. Complicava o quadro o fato de que era difícil um jovem professor desejar trabalhar nas distantes áreas rurais. No princípio, a remuneraçáo ficava ao encargo das sociedades escolares constituídas. E era comum que o mestre tivesse auxílio da comunidade para realizar atividades agrícolas em um pedaço de terra que lhe era emprestado, de modo a complementar sua subsistência.

Por isso, aprender a escrever, ler e contar - geralmente em alemão, embora também se registre o ensino da língua portuguesa como necessário às relaçóes com os demais habitantes locais usuários do idioma oficial -, compunha parte significativa e emblemática do repertório cultural da infância e juventude nas áreas de imigração, o que auxiliou na criação e manutençáo de um ambiente que diferia de outras regióes do Brasil, sinalizando para a existência de pequenas ilhas estrangeiras espalhadas pelo país.

Colhi relatos que revelam outras peculiaridades sobre a docência. Ewald Duwe 9 , outro descendente entrevistado, recordou algo mais sobre os mestres e os elementos da organização escolar, referindo-se à escola que se localizava na área central (Stadtplatz) do distrito Humboldt, na Colônia Hansa:

Primeiro comecei era a escola onde está hoje o sindicato. Era a escola alemã. No começo, lá, depois foi fechada. Porque essa escola era pertencente da igreja antiga [...]. Da escola eu só... tinha muito professor. Só tinha um pastor que dava 
aula, que chamava-se pastor Soboldt. Ele foi para Curitiba, ele vinha lá visitar a nossa classe de aula. E outro tudo que dava aqui que a gente nem lembra mais. Tinha [Pastor] Kinas e tinha... como é o outro lá... genro do Rutzen.

Ou seja, nas comunidades em que predominavam luteranos, dados os vínculos entre a igreja e a escola, os pastores acabavam também lecionando. Renate Rutzen Werner ${ }^{10}$, filha de próspero comerciante, estudou numa escola da regiâo conhecida atualmente como Vila Isabel, que se chamava Isabella-Strasse (Estrada Isabel). Lembrou-se de professores que atuavam na localidade onde estavam os negócios da família:

Antes do professor Tomelin, tinha um professor que se chamava Rodofo Zimmermann. Rodolfo Zimmermann. Ele também morava aqui na Vila, ele também era professor aqui. Claro, antigamente tinha outros, mas eu não me lembro. Desses dois eu me lembro. Depois também tinha o Ayroso, professor aqui, Holando Gonçalves... A gente tinha Português, tinha Matemática, História, Geografia, Desenho. Eu não me lembro se tinha Educação Física.

Outra pessoa ouvida foi Elly Früchting ${ }^{11}$, esposa de Willy. Afirmou que seu professor foi Rudi Zimmermann: "De Alemanha. Ele era da Alemanha mesmo. Mas ele dava aula em alemão e em português. Sabe, ele só conversou conosco em alemão. Só em alemão". Como registrei as memórias do casal Früchting em conjunto, obtive a seguinte resposta sobre a didática de uma professora de Willy:

Sim, ela ficava lá no canto dela. E chamava: Estrela, Antônio Carlos, todos os nomes. Chamava lá. Então ela dava um tempinho, então ela chamava outra palavra, outra palavra, outra palavra. Ela sempre deixava um intervalozinho para gente ter tempo para escrever, então ela depois corrigiu. E também ensinava a fazer cartas. É, ensinava. Uma vez, parece, por semana, se não me engano. Ou cada semana uma vez ela ensinava escrever cartas, também... para os filhos, para os pais. Era assim para a gente ter uma noção como é que faz uma carta. Carta comercial não me lembro. 
Ainda quanto às memórias daqueles que frequentaram o banco de alguma daquelas escolas inauguradas nos tempos mais remotos, continuemos a ouvir "Seu" Willy tratando das práticas pedagógicas no início década de 1920:

O que nos ensinavam? Era fazer contas, ler e escrever e História... Até que História era tão interessante, tão inteligente, tão bom, além de que... Nós... Quantos tijolos a gente queria pra um metro quadrado? Então 56, eu não sei esses tijolos que existiam naquele tempo, hoje são outros tijolos, hoje são outros tijolos, hoje precisa... 5.. 16.. 5 vezes 16 são 80, 6 vezes 16 são 96, não... Então hoje precisa 5 num metro de altura... 6? 6, né?... Então são 30, 5 vezes 6 são $30 \ldots$ tijolos!

São generosas suas lembranças da escola, agregando detalhes:

Outros dias era, em geral, era ler, escrever. Era ler pra ela, em alemão. Ela ficava ali perto e a gente tinha que ler. Ela ficava aqui [indicando com gesto como se revivesse a cena], para cada aluno, nós tinha que ler. Então, ela também fazia ditados! Ditados, também. Ela ditava. Ela chamava ditado lá do canto dela. Entäo, a gente tinha que escrever isso, ela chamava e depois apresentar pra ela... tinha escrito certo ou errado e por isso ela dava depois o... número, 1, 2, 45 !

Quanto aos aspectos curriculares, se por vezes o ensino era feito em língua alemã, ela era objeto de estudo sistemático. Mas isso não implicou que não houvesse a preocupação com a aprendizagem do português, embora o currículo centrasse efetivamente nos usos do idioma estrangeiro. Mesmo porque nas regiốes rurais a língua alemã não era apenas base da comunicação intrafamiliar, mas predominava nas relaçóes sociais mais amplas. Com isso, os descendentes de imigrantes mantinham representaçôes de que viviam em ambiente com características culturais mais vinculadas à Alemanha do que ao Brasil.

"Dona" Elly, que também estudou na escola Isabella-Strasse, lembra das brincadeiras no recreio. Sua dificuldade residiu em dizer como são faladas as palavras em português, uma vez que, embora bilíngue, fica mais à vontade 
quando conversa em alemão: "Esse não queria fazer, depois eu falo em alemão, depois eu fala... faules Ei" - traduzindo, o conhecido "ovo podre". Outras brincadeiras ou jogos que tem lembranças são o Versteckspiele, ou seja, o jogo de esconder, e o Fangenspiel, o conhecido pega-pega. A garotada adorava o Schaukel: um "balanço", geralmente feito sob as árvores, com a utilização de cordas que suportavam um pedaço de madeira sobre o qual a criança se equilibrava sentada, enquanto balançava sozinha ou com auxílio de outra. No âmbito da cultura da infância se cultivou não apenas a língua estrangeira, mas também aspectos lúdicos que reforçavam o parentesco e laços comunitários.

O depoimento confirma a divisão de sexo nas atividades: "Naquele tempo, não era permitido que, na hora do recreio, nós brincássemos juntos. Isso não era permitido. As moças brincavam sozinhas no lado delas e nós no lado nosso. A professora exigia. E quem ia lá perturbando as meninas a professora já vinha castigar eles". "Seu" Willy também falou dos brinquedos infantis:

Nós tínhamos uma... três ou quatro varas pra fazer de mastro. Os rapazes e as moças tinham um palmito, ele era preso aqui, e preso lá mais ou menos lá na frente, o resto solto. Equem ia até o fim, na caía, então ele era, era um... ganhava um número, né? E quando ele caía antes não era número, porque às vezes balançava, tuc!, ia lá pra baixo. Essa era uma brincadeira interessante. Quase um tipo de ginástica. Vamos dizer uma ginástica. Nós tínhamos lá essa [...].

Questiono sobre os movimentos: "Ah, nós ficava com o braço pra cima, esticava o corpo, descia, e quantas voltas! Uma cambalhota. Isso, isso, tudo isso nós fazia, foi muito bom". Configura minúcias daquele cotidiano, do que acontecia no pátio escolar, reconstituindo as cenas, povoando-as com crianças e seus folguedos, como se estivesse pintando um quadro de Brueghel:

É, mas era muito bom, dá força pra gente, nas pernas e nos braços... atividade física era muito bom. A gente inventava brincadeiras, correr um atrás do outro, quem corre mais ligeiro, e assim inventava, também, ela [a professora gostava]. Mas ela [a professora] gostava sempre quando nós fizéssemos uma ginástica, ela gostava mais. 
Seu imaginativo relato faz lembrar a Turnverein ou sociedade de ginástica, outra típica instituição trazida para o Brasil pelos alemães. Os aspectos lúdicos associados à escola e à infância são coincidentes com aqueles rememorados em estudo de Santos (2011). As memórias váo pouco a pouco mostrando como a escolarização contribuía para reafirmar a herança cultural comum.

\section{Das transformações impostas e da herança preservada}

A elaboração, no decurso da história, de um ambiente cultural distinto nas colônias de imigração estrangeira acabou gerando questóes polêmicas discutidas pela etnografia contemporânea. E nesse cenário, a criação, a propriedade e organização das escolas estrangeiras configurou um dos aspectos mais debatidos, dada sua vinculação estreita com a configuração de uma identidade étnicocultural que se erigiu como alienígena aos olhos do governo do Brasil.

Localizam-se notadamente no período do Estado Novo (1937-1945), interstício de ditadura comandado por Getúlio Vargas (1930-1945), diversos eventos relacionados à "campanha de nacionalizaçáo" com alvo nas colônias de imigrantes estrangeiros. De acordo com vários estudos reunidos por Pandolfi (1999), tanto sob o ponto de vista político, social e cultural como no específico plano educacional, as escolas "estrangeiras" foram alvo de ataque. Foram fiscalizadas, por vezes confiscadas e sua posse transferida para os municípios ou estados. Isto quando as medidas do nacionalismo náo causaram sua extinção pela impossibilidade de atender as exigências do governo brasileiro: proibição do uso da língua alemã e de materiais curriculares impressos neste idioma; substituição dos docentes e dirigentes escolares que não fossem brasileiros natos e que dominassem o vernáculo; inserção de disciplinas tratando de História e Geografia do Brasil, Educação Moral e Cívica e Educação Física, almejando uma nova formação cívica e patriótica dos descendentes de imigrantes, conformando as crianças de acordo com os princípios do ideário estadonovista.

Appel e Muysken (1996) mostram a importância da língua como fator de identidade entre grupos de imigrantes quando instalados em novas realidades. Assim, a questão da preservação da origem linguística teuta foi essencial na preservação da "germanidade". Mas, de acordo com Santos (2010, 2009), ao mesmo tempo foi o elemento de identidade étnica mais combatido pelo nacionalismo sob o governo Vargas. 
As memórias de Adele, que frequentou a escola na década de 1930, evidenciam a chegada dos ditames do nacionalismo às "escolas estrangeiras no Brasil”, quando lembra a proibição de falar alemão.

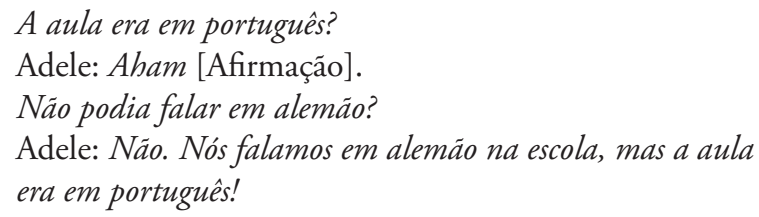

Outros rituais pedagógicos foram lembrados, dentre eles as provas anuais. $\mathrm{O}$ depoimento indica um fato já evidenciado em estudo sobre as práticas pedagógicas nesse período: era bastante elevado o índice de reprovaçáo (SANTOS, 1999). Pois no tempo da campanha de nacionalizaçáo, as crianças foram forçadas a aprender o Português, o que causou evasão e repetência:

Lembra se tinha prova para fazer?

Adele: Só esse provão, no fim do ano.

Ah, o provão! No fim do ano! E outras provas não tinha?

Adele: Não tinha!

Só essa prova muito grande! E se não passasse no provão, reprovava! Lembra se muita gente reprovava? Não conseguia a nota no provão?

Adele: Tinha bastante gente que não passava.

Perguntei sobre outros rituais pedagógicos e comemoraçóes. Curiosamente, as entrevistadas indicaram pouca presença ritualística, com alguns elementos que permitem inferir sobre práticas nacionalistas e de abrasileiramento, o que vai de encontro ao que demonstraram outras pesquisas.

Essas outras celebraçôes: Páscoa, Natal, não faziam nada na escola?

Edeltraut: Não! Não! Nada, absolutamente nada.

Quem fazia isso era só na igreja? A igreja fazia essas celebraçóes?

Adele: Não!

Edeltraut: No meu tempo, depois do culto infantil, ai já tinha um pouquinho assim, mas era só mesmo no mês de setembro e Natal. Aisim, o hasteamento da bandeira, aquilo 
ali era sagrado e todo sábado. Hasteamento da bandeira, hino, declamação de versos. Dos versos não me recordo mais de nenhum!

Os versos assim sempre falando do Brasil? [Perguntei, à busca de elementos do nacionalismo em voga].

Edeltraut: Exatamente

Patriotismo.

Edeltraut: Exatamente!

Na época da tia Adele, lembra se tinha isso também da pátria?

Adele: É a mesma coisa! Tinha versos.

Outro estudo alicerça o argumento de que o ritual serviu a uma formação específica da infância no período republicano, pois a escola pública primária que se buscou instituir devia incorporar novas orientaçóes, afirmando um regime intimamente vinculado ao nacionalismo. Santos (2012a, 2012b) mostra que, sobretudo nas décadas de 1930 e 1940, as instituiçôes escolares foram utilizadas como ambiente estratégico da campanha de nacionalização, sendo que os rituais buscavam reforçar o objetivo da formação de inspiraçáo nacionalista: "abrasileirar". Destaca-se o escopo formativo político-pedagógico do ritualismo. Participavam das cerimônias os alunos da escola capitaneados pelos seus professores, mas também autoridades e a comunidade em geral, notadamente os pais das crianças. Alguns documentos citam discursos proferidos pelos professores. Parte dos atos era realizada em função de datas alusivas à Independência do Brasil, à Proclamação da República, ao Dia da Bandeira ou comemoravam personagens da história. Incluíam hinos, principalmente aqueles oficiais como o Hino Nacional, o Hino à Bandeira e o Hino da Independência, mas também outros dedicados a Tiradentes ou o presidente Vargas. Entoavam-se cançóes cívicas que exaltavam o Brasil Novo e a postura que se desejava das crianças e jovens, os futuros cidadáos. Havia recitação de poemas de inspiração nacionalista com títulos como $O$ Brasil, Saudação à Bandeira, A Independência, Defendamos o Brasil e Pátria Sacrossanta. Os títulos apresentados sugerem a veneração da terra brasileira, dos seus heróis e feitos, alinhando-se com uma perspectiva histórica que atribuía apenas a alguns sujeitos o protagonismo histórico. Havia programas que incluíam atividades teatrais, além de jogos e brinquedos. Apareciam, também, demonstrações de Educação Física, ginástica ou exercícios ao ar livre. Um caráter étnico emana de títulos como Os Pretinhos da Guiné, A 
Baiana e Sitio de Caboclo. Mas principalmente se festejava o presidente Getúlio Vargas: programas registram a inauguração dos retratos de Vargas nas escolas. Em alguns casos, o ritual era uma festa escolar destinada a prover fundos e incluía venda de bebidas, assados e café com doces. Podia incluir atividades como partidas de futebol entre times regionais, tiro ao alvo e a presença de grupos musicais que animavam a celebração - estas duas últimas atividades características da cultura alemã que resistia. Em algumas ocasióe sosrituais podiam ir além dos muros da escola, como passeatas, marchas e desfiles nos arredores das escolas envolvendo as crianças, podendo ser entendidos como formação militarizada, também atribuída às atividades de educação física. Nesse sentido, a formação da infância coaduna com a militarização infantojuvenil incorporada às escolas primárias desde as primeiras décadas do século passado, quando se tomou o escotismo e o serviço militar como padróes de modelagem.

Fica evidente, novamente, a centralidade da questấo linguística nos processos de nacionalização preconizados e que, em maior ou menor grau, tinham lugar nos rituais escolares. Comprova tal aspecto a frequente referência às Ligas Pró-Língua Nacional, ressaltadas também na pesquisa de Luna (2000), que tinham como tarefa combater os problemas gerados pelo bilinguismo da população infantil: as crianças falavam o alemão como primeira língua, apresentando problemas na aprendizagem da escrita e da fala em português, sendo citadas correçóes dos textos infantis e também de pronúncia, o que se buscou fazer através dos cantos e do recitar, por exemplo. As cerimônias e festas escolares delineavam um elenco de ritos com finalidade explícita: contribuir para a nacionalização da população infantil em meio cultural com presença de aspectos estrangeiros. O conflito estava em decurso: de um lado as comunidades compostas majoritariamente por imigrantes e seus descendentes buscando preservar os elementos culturais de sua identidade; de outro os ditames do nacionalismo buscando apagar uma herança.

Dados colhidos nos depoimentos estão em consonância com perspectivas historiográficas que localizaram as mesmas prerrogativas da campanha de nacionalização da era Vargas noutras fontes documentais ligadas à escola tais como livros didáticos, cadernos escolares, fotografias e termos de visita de inspeção, bem como na literatura da época que serviu de propaganda para o regime de governo (PANDOLFI, 1999; GUASTINI, 1943; BETHLEM, 1939). Evidencia-se que há uma natureza peculiar nas propostas curriculares previstas 
pela legislação da época, particularmente para as instituiçôes escolares situadas em núcleos de colonização alemã (SANTOS, 2010). Naquele momento, a "germanidade" presente era combatida e conflitava com a "brasilidade".

As depoentes trouxeram lembranças sobre a ritualidade, sendo que aparecem os festejos de sete de setembro, fartamente comemorado em tempos de exaltaçáo nacionalista:

Adele: $E$ tinha festa de sete de setembro.

Edeltraut: Sete de setembro.

Adele: Festa de sete de setembro era grande.

O outro hino talvez era o hino da independência tia Adele?

Adele: $E_{\text {. }}$

Edeltraut: Canta uma parte do hino.

Esse tu lembras direitinho.

Edeltraut: Esse eu lembro.

Durante a nacionalização houve mudanças na estrutura curricular, sendo que disciplinas como História, Geografia, Educação Moral e Cívica e Educação Física foram utilizadas com finalidade de inculcaçáo ideológica, aliadas a uma prática tradicional. Nota-se que mesmo as respostas de Edeltraut, que estudou nos anos 1950, podem ser analisadas sob os efeitos que o nacionalismo imprimiu à educação escolar em Santa Catarina, como indicou investigação de Santos (2008) sobre a permanência dos ideais da campanha de nacionalização mesmo após 1945.

História era muito difícil naquela época?

Edeltraut: Sim! Era a matéria mais dificil, porque tinha muita coisa que a gente tinha que decorar folhas, folhas e mais folhas que às vezes a gente tinha que decorar de um dia para outro.

De um dia para outro?

Edeltraut: De um dia para outro!

Tipo esse texto dessa cartilha: Tomé de Souza. Decorava tudo? Edeltraut: Sim!

Primeiro governador geral do Brasil foi o fidalgo português Tomé de Souza!

Edeltraut: Sim, exatamente!

Ai tinha que falar tudo isso?

Edeltraut: Tudo exatamente como estava escrito na cartilha. 
Mas geralmente a professora passava no quadro para que todo mundo tivesse que copiar, cada um em seu caderno e decorar! Tinha que decorar o texto, a história inteirinha de um dia para outro, para depois ela tirar uma perguntinha ou outra nas provas!

Não podia inventar nada?

Edeltraut: Não, não podia inventar criar nada! Só direitinho como estava escrito no livro

Isso na História tinha pontos e na Geografia também tinha pontos para decorar?

Edeltraut: Também tinha ponto! Mas geografia era pouca coisa

Geografia o que estudava? Geografia do que? Falava do que assim?

Edeltraut: Falava do... como é que vou dizer! Da quilometragem, de quanto é que media o país e coisa e tal, tudo assim!

Mas só do Brasil? Chegava a falar, por exemplo, de Santa Catarina e Corupá? Ou do mundo?

Edeltraut: De Corupá, nessa época não se falava muito! Era do Estado ou do país! Do município não! Hoje em dia tem muita coisa, eles aprendem sobre o município, nos não aprendemos nada assim do nosso município, na época não tinha nada, nada!

Sobre outros paises? Fora do Brasil também não se aprendia? Edeltraut: Pouca coisa!

Percebeu-se ainda a herança de militarização na formação infantil. Nas primeiras décadas do século passado essa influência foi aliada aos ideais do escotismo, apresentado juntamente com o aspecto formativo militar - apoiados na obediência e respeito de base cívico-patriótica. Este elemento aparece na fala das representantes de duas geraçóes:

E como era? Tinha formação de filas antes de entrar na sala? Ou ia todo mundo para a sala?

Edeltraut: Sim! Todo mundo em fila, tudo bonitinho, a professora chamava e todos em forma, um atrás do outro enfileirado, ai entrava um seguindo o outro não tinha aquele corre-corre de todo mundo sair correndo ali e entrar porta adentro, isso não tinha! 
Adele: Tinha que por a mão no ombro do outro..

Edeltraut: É uma mão no ombro do outro, não podia olhar para o lado para ver o que estava escrevendo e coisa e tal. E ai de quem levantasse a cabeça, ou virasse os olhos pra olhar porta afora quando passava uma carroça na estrada. Ai, ai, ai [risos]. Nâo tinha isso como hoje em dia, de se levanta e olhar janela a fora ou coisa e tal!' Ali não podia nem erguer a cabeça ou virar a cabeça para o lado pra olhar! Foi bom assim, pelo menos a gente respeitava e aprendia alguma coisa.

Falas como essa levam a pensar nos mecanismos de controle, na disciplina. Willy também apresentou suas concepçóes sobre as atitudes docente e discente:

Era rigorosa, ela era rigorosa. Era muito boa, eu gostei muito da minha professora... Eu nunca vou esquecer, enquanto eu vivo, náo vou esquecer a minha professora. Porque era uma professora que gostava quando a gente aprendia, e quando a gente fazia esforço pra aprender, ela via a vontade, né? A boa vontade ou não ter vontade. Sendo um vadio ela não gostava, ela botava até nos bancos separado quem não queria aprender. Eu passei muito bem com a minha professora, muito bem. Aprendi, eu aprendi bem.

[...] Puniçóes? As puniçôes era aquele... Ela chamava a atençâo hoje, chamava a atençâo amanhã, no terceiro dia, ele ficou preso. Meio-dia, no meio-dia não podia ir pra casa, ficava meia-hora etc Às vezes que eles melhorassem um pouco. Tinha três na nossa escola que não melhoravam de jeito nenhum. Entraram vadios, saíram vadios!

Outras vozes trouxeram aspectos sobre a disciplina e o controle:

Se fazia alguma coisa de errado, o que acontecia? Coisa errada na sala?

Adele: Não, eu nunca apanhei, mas presa eu já fiquei.

Presa?! Como é isso tia Adele? Conta.

Adele: Quando nós faziamos bagunça na escola [risos], ríamos, um copiava do outro e dai tínhamos que ficar presas.

Equanto tempo?

Adele: Só uns minutos.

Uns minutos no final da aula? 
Adele: E no recreio também. Conforme, quando era antes do recreio, ficamos no recreio. E se for depois do recreio, ficamos no final da aula.

E tu lembras se alguma pessoa fazia coisa errada, o que a professora fazia? Batia? Como era?

Adele: Ah, "escarniava” com a régua!

Com a régua na mão?

Adele: Na bunda [risos].

Ah, na bunda mesmo! Tanto rapaz como menina?

Adele: Tanto faz

Mas era dificil as pessoas fazerem isso? Bagunça, ou acontecia pouco?

Adele: Ela era mesmo rigorosa com nós

A professora da tia Adele quem era?

Adele: Dona Marta.

A Marta! Então ela era rigorosa! E era difícil então alguém fazer bagunça?

Adele: É! Quando ela foi na cozinha cuidar do almoço.

[risos] Enquanto ela ia na cozinha vocês começavam a conversar e tatata...

Adele: E tinha fresta assim na porta, que ela olhava.

Dai se ela via alguém fazendo coisa errada?

Adele: Dai era rigoroso.

\section{Alemanha perdida?}

Quando perguntei sobre o significado de frequentar a escola para a vida, tive as algumas respostas interessantes. Segundo Willy, a escola foi "superimportante pra mim. Eu queria ficar até o fim do ano, para ter o terceiro, mas o pai näo deixou, sabe como era... Precisou eu em casa, eu era o mais velho! Pobre, pobre como um rato nós éramos?'. E continuou falando, com orgulho, de sua atividade profissional como administrador contábil de uma cooperativa agrícola, cargo que ocupou até sua aposentadoria. Para ele, o que a escola ensinou, associado a seu gosto pela Matemática, calcou o seu êxito no trabalho: "Ah, gostava muito. Cálculos?". Já para Adele, a escola "era importante, agora ao menos sei escrever um pouco, fazer contas...".

O ensino nessas escolas, geralmente feito com o uso da língua alemá e contemplando aspectos das culturas teuta e europeia, ajudou a criar ambientes 
com valores étnicos peculiares, contrastantes com a realidade brasileira: "O principal efeito das escolas particulares 'étnicas' foi o fato de terem estimulado o uso das línguas de origem dos imigrantes, às vezes até a quarta ou quinta geração" (SEYFERTH, 1990, p. 53).

As memórias dos descendentes de imigrantes ouvidos para compor este estudo ratificam os aspectos indicados quanto à constituição de um conjunto de instituiçóes próprios das zonas coloniais, que tinha uma finalidade social definida e que possibilitou a geração histórica de uma distinção de fundo étnico que persistiu no tempo. Ou seja, os imigrantes inauguraram escolas comunitárias nas colônias que imprimiram uma marca identitária que perdurou mesmo após a compulsória extinção ou transformação institucional, embora aquelas escolas tenham sido alvo da campanha de nacionalização.

A questão linguística emerge como já se destacou noutras pesquisas, e pode-se estimar o impacto que isto teve na aprendizagem das crianças que tinham como língua materna o alemão e que subitamente se viram obrigadas a utilizar exclusivamente o português nas escolas de imigrantes, porque isso era o que ditavam as políticas educacionais nacionalistas. Apesar das exigências de submissão, resistências foram geradas. Mesmo nos momentos históricos de combate à etnicidade de origem teuta, elementos de resistência cultural persistiram:

Eno recreio daí falavam alemão assim, entre ou não podia? Adele: Não!

Nâo podia? Nem as cantigas de roda? Nada?

Adele: Nada, nada! Só em português!

Só em português!

Adele: Aham. [Afirmação].

Por que será que tinha isso? Em casa as pessoas falavam em alemão?

Adele: Sim! Isso era tão difícil

É! Quando a tia foi pra escola já sabia falar o português?

Adele: Bem pouquinho! Mas a dona Marta explicou em alemão daí.

Ah, dai ela explicou em alemão para ti?

Adele: Aham. Por que todo mundo na sabia falar. Tinha poucos que sabia falar

E ai ela explicou em... 


\section{Adele: Alemão! \\ Em alemão. Depois, tu logo aprendeu? \\ Adele: $E$.}

Passo a um trecho do depoimento da jovem Maoren, em que explicou como havia usado "estrategicamente" seu repertório cultural de origem alemã na sala de aula. Explicou que se referia ao período de sua formação em nível médio, em 2006, numa instituição localizada na área central da cidade onde mora atualmente. Foi para onde se transferiu depois de ter completado o ensino primário na Escola Municipalizada Rio Novo, que teve origem na antiga escola alemá da comunidade, mas que foi fechada na década de 2000. Concluiu as séries restantes do Ensino Fundamental na Escola Municipal Francisco Mees, originada da antiga escola alemã da Isabella-Strasse.

Maoren: Fiz o $2^{\circ}$ grau agora, faz 3 anos, depois disso como
não tinha mais, que já era na Vila Rutzen. Ai $2^{\circ}$ grau
completei no centro, no Teresa Ramos, que é o único lugar
que tem disponivel $2^{\circ}$ grau. Nós talvez era mais chique,
passava a cola tudo em alemáo, quando o professor náo
falava. Chegava na hora da prova o número da questáo
e a resposta em alemáo, todo mundo disfarçava,
ninguém sabia alemáo. Colava de um jeito muito simples.
(grifos nosso).

De modo geral, pode-se afirmar que a perpetuação de memórias positivas ou traumáticas da escolarização é usada para reforçar e reafirmar afeição, consanguinidade e pertencimento a uma herança cultural comum. Assim, as representaçóes mentais dos habitantes reconstituem e perpetuam a ideia de fazer parte de uma Europa brasileira. Esta, que embora combatida, acabou perdurando ao longo da história nas relaçôes sociais. Em função do processo de constituição cultural dessas regiôes meridionais do Brasil, mesmo que em alguns momentos conflituosos e ambíguos, os descendentes de imigrantes alemães mantiveram a ideia de que esta regiấo representa a Europa brasileira.

Há ainda vários indicadores contemporâneos que mostram a preservação social da "germanidade". Muitas cidades do interior catarinense investem na conservação de uma imagem de semelhança a regióes europeias de onde partiram os pioneiros imigrantes alemáes. Por exemplo, realizam suas próprias versôes de festas típicas germânicas como a Oktoberfest, a Schützenfest (Festa dos 
Atiradores) e a Stammtisch (originalmente, encontro em torno de uma mesa para comer, beber e conversar), e também incentivam a preservação arquitetônica dos edifícios de estilo enxaimel, entre outras iniciativas de resgate da herança étnico-cultural germânica que constituiu suas comunidades.

Resulta uma mescla de elementos de raiz histórica fincada na imigração com outros que sofreram mudanças que podem ser vistas como expressão de um processo de folclorização de hábitos culturais herdados. No âmbito educacional, atualmente os sistemas municipais incluem várias escolas que oferecem a língua alemã em seus currículos. Portanto, depois da busca pelo processo de extinção da utilização desse idioma estrangeiro pelos imigrantes e sua descendência ocorrido na campanha de nacionalização da era Vargas, hoje se assiste à implementação de iniciativas de sua (re)aprendizagem, pois como reiteram os linguistas Appel e Muysken (1996, p. 26, tradução nossa), parafraseando um trabalho de Fishman: "a língua é o símbolo por excelência da etnia" e sua importância "se vê amplificada pelo fato de que se emprega para sustentar outras experiências étnicas".

Por fim, o exercício analítico-descritivo proposto neste estudo me conduz à obra literária "Um rio imita o Reno". Neste romance, o escritor Vianna Moog (1939) descreve as relaçóes sociais e culturais travadas ao longo da história da fictícia Blumenthal, marcadas por atitudes de racismo. Chama assim atenção para os fenômenos que podem marcar profundamente grupos humanos e convida a refletir sobre as condiçóes de formaçáo humana com as quais convivemos. Sob tais questionamentos étnicos e éticos, revitalizo minha pergunta propulsora: o sul brasileiro abriga hoje uma "Alemanha perdida"?

\section{Notas}

${ }^{1}$ Entrevista concedida em Corupá, SC, no dia 19 maio 1998.

${ }^{2}$ Um detalhado estudo sobre as relaçóes entre o processo de colonização no sul do Brasil é apresentado por Santos (2012a, 2012b), onde são descritos e analisados vários aspectos da criação e desenvolvimento da Colônia Hansa.

${ }^{3}$ Entrevistas concedidas em Corupá, SC, nos dias 22 abril de 1998 e 13 julho de 2009. 
${ }^{4}$ As entrevistas foram realizadas em 1998 e em 2009, com a presença simultânea das representantes de três geraçóes distintas e que estudaram na mesma instituição.

${ }^{5}$ Aqui aludo à herança luterana materializada no clássico texto de Martinho Lutero (1995), escrito em 1530, intitulado Uma prédica para que se mandem os filhos à escola. Esse dado cultural de valorização da escola é marcante entre os imigrantes alemães luteranos.

${ }^{6}$ Entrevista concedida em Corupá, SC, no dia 22 de abril de 1998.

${ }^{7}$ Entrevista concedida em Jaraguá do Sul, SC, no dia 6 de maio de 1998.

${ }^{8}$ Este importante informante para a escrita da etnografia das escolas da imigração estrangeira, dono de prodigiosa memória, faleceu em 2012. Ficam estes escritos como homenagem.

${ }^{9}$ Entrevista concedida em Corupá, SC, no dia 19 de maio de 1998.

${ }^{10}$ Entrevista concedida em Corupá, SC, no dia 2 de julho de 1998.

${ }^{11}$ Entrevista concedida em Corupá, SC, no dia 19 de maio de 1998.

\section{REFERÊNCIAS}

APPEL, René; MUYSKEN, Pieter. Bilinguismo y contacto de lenguas.

Barcelona: Ariel, 1996.

BETHLEM, Hugo. Vale do Itajaí: jornadas de civismo. Rio de Janeiro: José Olympio, 1939.

GUASTINI, Raul. Ideário Político de Getúlio Vargas. São Paulo: Revista dos Tribunais Ltda., 1943.

LUNA, José Marcelo F. O português na escola alemã de Blumenau: da formação à extinção de uma prática. Itajaí: Ed. da Univali; Blumenau: Edifurb, 2000.

LUTERO, Martinho. Obras selecionadas: uma prédica para que se mandem os filhos à escola. São Leopoldo: Sinodal; Porto Alegre: Concórdia, 1995. v. 5. 
PANDOLFI, Dulce. (Org.). Repensando o Estado Novo. Rio de Janeiro: Fundação Getúlio Vargas, 1999.

RAMBO, Arthur Blásio. A escola comunitária teuto-brasileira católica. São Leopolodo: Editora da Unisinos, 1994.

RAMBO, Arthur Blásio. A escola comunitária teuto-brasileira católica: a associaçấo dos professores e a escola normal. São Leopoldo: Editora da Unisinos, 1996.

RAMBO, Arthur Blásio. O teuto-brasileiro e sua identidade. In: FIORI, Neide Almeida (Org.). Etnia e educação: a escola "alemâ" do Brasil e estudos congêneres. Florianópolis, SC: Editora da UFSC; Tubarão: Editora da Unisul, 2003. p. 63-92.

SANTOS, Ademir Valdir. Educação e Imigração: a escola alemã do Rio Novo. 1999. 246f. Dissertação (Mestrado em Educação) - Universidade Federal de São Carlos. São Carlos, 1999.

SANTOS, Ademir Valdir. O Estado Novo, o período pós 1945 e as escolas primárias catarinenses: (des)nacionalização do ensino estrangeiro? Revista HistedBR on-line, Campinas, SP, n. 32, p.65-84, dez. 2008.

SANTOS, Ademir Valdir. A política educacional nacionalista e o aspecto linguístico: vestígios na escola primária. Revista Brasileira de Estudos Pedagógicos, Brasília, v. 90, n. 225, p. 511-527, set./dez. 2009.

SANTOS, Ademir Valdir. Educação e nacionalismo: configurando a escola primária catarinense na Era Vargas. Revista Brasileira de História da Educação, Campinas, SP, n. 24, p. 83-111, set./dez. 2010.

SANTOS, Ademir Valdir. Quando eu era criança... memórias da infância e da escola no cenário da imigraçáo alemá. In: FARIA FILHO, Luciano Mendes; ARAÚJO, Vania Carvalho (Org.). História da educação e da assistência à infância no Brasil. Vitória: EDUFES, 2011. p. 97-124.

SANTOS, Ademir Valdir. Educação e colonização no Brasil: as escolas étnicas alemãs. Cadernos de Pesquisa, São Paulo, v. 42, n. 146, p. 536-561, maio/ago. 2012a. 
SANTOS, Ademir Valdir. Cerimônias e festas escolares no Brasil republicano: o ritualismo como expressão do nacionalismo (décadas de 1930-1940). In: CONGRESSO LUSO-BRASILEIRO DE HISTÓRIA DA EDUCAÇÃO, 9., 2012, Lisboa. Atas... Lisboa: Instituto de Educação da Universidade de Lisboa, 2012b. p. 2985-2996. 1 CD-ROM.

SEYFERTH, Giralda. Imigração e cultura no Brasil. Brasília: Editora da UnB, 1990.

MOOG, Clodomir Vianna. Um rio imita o Reno. Porto Alegre: Globo, 1939.

WILLEMS, Emilio. A aculturação dos alemães no Brasil: estudo antropológico dos imigrantes alemães e seus descendentes no Brasil. 2. ed. São Paulo: Editora Nacional, 1980.

TÍTULO definitivo de propriedade. Hammonia, 1918. 


\section{A lemania perdida? Escolarización de los niños en las colonias de inmigrantes alemanes en el sur de Brasil}

\section{Resumen}

Durante los siglos XIX y XX, la región sur de Brasil recibió miles de familias de inmigrantes alemanes. Fundaron escuelas de la comunidad dentro de las colonias que se convirtieron en una marca de identidad étnica. Pero en las primeras décadas del siglo pasado, las escuelas eran el objetivo de las campañas nacionalistas solicitando su cierre o una transformación completa. Este estudio tiene como objetivo analizar y recuperar los recuerdos de la escuela, basado en entrevistas con representantes de tres generaciones de descendientes de inmigrantes alemanes. Los datos recogidos describen aspectos de las trayectorias escolares de los sujetos y son analizados a partir de una perspectiva etnológica, por fuentes documentales y en diálogo con otras investigaciones sobre la relación entre la educación y la inmigración en tierras brasileñas. Muestra que los niños se vieron obligados a aprender portugués y cambiar su comportamiento, lo que provocó la deserción y la repetición. También constatamos que la perpetuación de los recuerdos positivos o traumáticos escolaridad se utiliza para reforzar y reafirmar el afecto, el parentesco y pertenencia a un patrimonio cultural común. Por lo tanto, las representaciones mentales de los habitantes perpetúan la idea de ser parte de una Europa brasileńa, junto con la preservación social de "alemanidad". Palabras claves: Inmigración. Niños. Escuela primaria.

\section{Lost Germany? Children's schooling in colonies of german immigrants in the south of Brazil}

\section{Abstract}

During the 19th and 20th centuries, the South region of Brazil received thousands of German immigrants' families. They opened up community based schools inside the colonies that became an ethnic mark of identity. But in the first decades of last century those schools were the target of nationalist campaigns which required its closing or a complete transformation. This study aims to remember and analyze memories about the school based on interviews with representatives of three generations of descendants of German immigrants. Concerning the methodology, their schooling trajectories are analyzed under an ethnological perspective based on the testimonies, by documentary sources and in dialogue with other researches on the relationship between education and immigration in Brazilian lands.It shows that children were forced into learn Portuguese and change their behavior, which caused evasion and the children were held back. It is assumed that the perpetuation of positive or traumatic memories of schooling is used to reinforce and reaffirm affection, consanguinity and belonging to a common cultural heritage. This way, the mental representations of the inhabitants perpetuate the idea of making part of a Brazilian Europe. Besides the social preservation of "Germanity".

Keywords: Immigration. Children. Elementary school. 


\section{Ademir Valdir dos Santos}

E-mail: ademir.santos@ufsc.br

Recebido em: 8/4/2013

Versão final recebida em: 10/08/2013

Aprovado em: 14/8/2013 